For: GRL

November 1, 2001

Advection from the North Atlantic as the forcing of winter greenhouse effect over Europe

J. Otterman ${ }^{1}$, J. Angell ${ }^{2}$, R. Atlas ${ }^{3}$, D. Bungato ${ }^{4}$ (dbungato(a dao.gsfe.nasa.gov), S. Schubert , D.Starr ${ }^{3}$ (starruclimate.gsfc.nasa.gov), J. Susskind ${ }^{3}$, M.-L.C. Wu ${ }^{3}$

Key words: greenhouse effect in Europe;

maritime-air advection; climate fluctuations, climatic feedback

1. Land-Atmosphere-Ocean-Research; at Data Assimilation Office, Code 910.3

NASA GSFC, Greenbelt, MD 20771 [tel:1(301)286-1312; fax: 1(301)286-2323]

2. NOAA, Silver Spring, MD, Consultant

3. Laboratory for Atmospheres, NASA GSFC, Greenbelt, MD

4. Science Applications International Corporation, Beltsville, MD 


\section{For: GRL}

Summary

\section{"Advection from the North Atlantic"}

In late winter, flow from the North Atlantic brings warm air masses at low level into Europe. The rise in near-surface temperature can be called the direct effect of advections. Since the atmospheric lapse rate becomes steeper, vertical motions become stronger. Convective motions elevate water vapor into higher levels, and clouds form.

As a result, heat losses to outer space are reduced, reinforcing the direct effect of advection. 
Abstract. In winter, large interannual fluctuations in the surface skin temperature are observed over central Europe: we observe a difference of $9.8 \mathrm{~K}$ comparing warm February 1990 with cold February 1996 for the region $50-60^{\circ} \mathrm{N} ; 5-35^{\circ} \mathrm{E}$. Previous studies show that advection from the North Atlantic constitutes the forcing to such fluctuations. The advection is quantified by Index $I_{n a}$, the average of the ocean-surface wind speed over the eastern North Atlantic when the direction is from the southwest (when the wind is from another direction, it counts as a zero speed to the average). Average $I_{\text {nat }}$ for February 1990 was $10.6 \mathrm{~m} \mathrm{~s}^{-1}$, but for February $1996 \mathrm{I}_{\mathrm{na}}$ was only $2.4 \mathrm{~ms}^{-1}$.A large value of $I_{n a}$ means a strong southwesterly flow which brings warm and moist air into Europe at low level, producing a steeper tropospheric lapse rate. Strong ascending motions result, which we observe in February 1990 at $700 \mathrm{mb}$. The near-surface moisture rises to higher (and cooler) levels, producing clouds and precipitation. Total preciptable water and cloud-cover fraction have larger values in February 1990 than in 1996. The difference in the greenhouse effect between these two scenarios can be translated into a virtual irradiating source of $2.6 \mathrm{~W} \mathrm{~m}^{-2}$ above the February 1990 atmosphere, which, as an order of magnitude estimate, contributes to the warming of the surface by $2.6 \mathrm{~K}$. If we accept this estimate as numerically pertinent, the direct effect stands as $7.2 \mathrm{~K}(9.8 \mathrm{~K}-2.6 \mathrm{~K})$, and therefore its greenhouse-effect reinforcement is by $36 \%$. This constitutes a substantial positive feedback to the direct effect, which is the inflow of warm air to the low troposphere over Europe. 


\section{Introduction}

Strong interannual variability characterizes winter surface temperature in midlatitude Europe, $50-60^{\circ} \mathrm{N} ; 5-35^{\circ} \mathrm{E}$. With the winter-sun low above the horizon, and low absorptivity (high albedo) of the surface when snow-covered, advection from the oceans effectively controls the climate of the adjoining continent, as shown by Hurrell (1996), for instance. The surface of the North Atlantic is much warmer than that of mid-latitude Europe, whereas the Arctic can be colder, so that the temperatures on the European continent depend on the wind direction. Circulation patterns over the North Atlantic and Europe fluctuate with the North Atlantic Oscillation (NAO), the stage of which is quantified by an Index (Rogers, 1997). Recently, a new index, $I_{\text {na }}$, has been developed based on the strength of the ocean-surface southwesterlies over the eastern North Atlantic. $I_{n a}$ apparently is a more relevant measure than the NAO Index for quantifying the maritime-air advection as the forcing to higher winter temperatures in Europe (Otterman et al., 1999).

Our aim is to assess the dependence of the winter greenhouse effects over Europe on the value of $I_{\text {na. }}$. In this season of low sun at these latitudes, the radiative effects of clouds and water-vapor tend to increase the surface temperature. Because the daytime reduction of insolation predominates, an opposite effect characterizes other seasons (Otterman et al., 2000; Sun et al., 2000). In our preliminary analysis, we compare high$I_{\text {na }}$, warm February 1990 with the opposite scenario in February 1996.

\section{Datasets used in the study.}

From the Special Sensor Microwave/Imager, SSM/I, aboard the DMSP satellites, a large dataset of surface wind speeds over the global oceans has been derived. 
Variational Analysis Method, VAM, was selected to derive wind-vector data. In this method, the SSM/I retrievals (that is, the measurements of speed) are combined with independent wind observations to produce consistent fields of wind speed and direction. The resulting global ocean-surface dataset is appropriate for climate analysis (Atlas et al.,1996).

The Pathfinder Path A dataset is compiled from measurements in numerous thermal and microwave bands basic to the TIROS Operational Vertical Sounder, TOVS, aboard polar-orbiting NOAA satellites. Temperatures, fluxes, water vapor, and cloudiness at various levels are inferred (Susskind et al., 1997). Monthly anomalies with respect to the 1979-2000 averages have been derived.

The ECMWF dataset is part of the Basic Level III-A analysis product with the ECMWR/WCRP Global Atmospheric Data Archive. In our study, we use ECMWF data for observing vertical motions at $700 \mathrm{mb}$.

Parts of our study are based on the National Centers for Environmental Prediction, NCEP/NCAR, Reanalysis dataset, which extends from January 1948 essentially to the present. Improvements in the analysis were introduced when satellite measurements became available (Kalnay et al., 1996; Kistler et al., 2001). The years for which we extract the data fall in this latter period.

\section{North-Atlantic winds as control of the greenhouse factor in central Europe.}

We examine here the influence of the maritime-air advection on the greenhouse effects in Europe. The strength of the warm advection is quantified by a specific Index, $I_{\text {na }}$, of the ocean-surface southwesterlies over the eastern North Atlantic. From the SSM/I 
dataset (Atlas et al.,1996), we evaluate at $45^{\circ} \mathrm{N} ; 20^{\circ} \mathrm{W}$ pentad-averages of the wind speed from all the observations reporting the direction from the quadrant $180^{\circ}-270^{\circ}$. When the direction is not southwesterly, the speed is counted to the average as a zero speed. The Index $I_{\text {na }}$ derived by this approach is plotted in Fig. 1 for the winters and early spring $1989 / 90$ and 1995/96, that is, for the 24 pentads from Dec. 2-6 to March 27-31 of next year. The average $I_{n a}$ for February (averaging six pentads) 1990 is about $10.6 \mathrm{~m} \mathrm{~s}^{-1}$, but only about $2.4 \mathrm{~m} \mathrm{~s}^{-1}$ for February 1996.

This large difference in $I_{n a}$ strongly affects the surface (skin) temperature $T_{s}$ in central Europe, $50-60^{\circ} \mathrm{N} ; 5-35^{\circ} \mathrm{E}$. There are no high mountains between the Atlantic and the eastern edge of this strip, and thus it can be regarded as a "corridor" for low-level flow. The maps of $T_{s}$ (from Pathfinder Path A dataset) are shown as Fig. 2 for February 1990 (upper Figure) and February 1996 (middle Figure). The data have been normalized to what the observations would have been at $7 \stackrel{30}{-} \mathrm{AM}$, to remove satellite orbit differences. We observe area-average temperatures $272.9 \mathrm{~K}$ and $263.1 \mathrm{~K}$, respectively for the two time periods (see Table 1). The difference, $9.8 \mathrm{~K}$, is consistent with the sensitivity slightly above $1.0 \mathrm{~K} / \mathrm{m} \mathrm{s}^{-1}$ of the February surface-air temperature in Europe to an increase in $I_{n a}$, analyzed by Otterman et al. (1999). We stress here that the high value of $T_{s}$ in 1990 represents the combined consequences of the inflow of warm air (the direct effect), and of the enhanced greenhouse effect that this low-level inflow produces (which we regard as the feedback).

We present in Table 1 the Surface Longwave Emission, SLE, calculated as:

$$
\operatorname{SLE}=\varepsilon \sigma T_{S}^{+}
$$

where $\varepsilon$ is the surface emissivity (taken as 0.95 ) and $\sigma$ is the Stefan-Boltzmann constant 
The air masses advected from the North Atlantic in the strong flow in February 1990 were certainly moist. The total precipitable water $\mathrm{W}\left(\mathrm{g} \mathrm{cm}^{-2}\right)$ in central Europe was larger by more than 70\% in February 1990 than in February 1996, as illustrated in Fig. 3, and given in Table 1 (from Pathfinder Path A). It is interesting to note that the weak winds in 1996 were effective in advecting moisture only to about $20^{\circ} \mathrm{E}$; beyond this longitude the atmosphere was quite dry, with $\mathrm{W}$ values below $0.6 \mathrm{~g} \mathrm{~cm}^{-2}$. In contrast, the strong winds of 1990 advected moisture to at least $1 \mathrm{~g} \mathrm{~cm}^{-2}$ all the way to the easternmost boundary of the region.

The moisture advected at low-tropospheric levels is lifted to higher levels, and clouds form, typically with a half-a-day delay. Cloud fraction was larger in 1990 than in 1996, as we report from the NCEP/NCAR Reanalysis. Differences between the two periods were greatest in the northern parts: $15 \%$ for the medium-level clouds (between 678 and $350 \mathrm{mb}$ ), $30 \%$ for high clouds (above $350 \mathrm{mb}$ ), see Fig. 4 , and also strong in the southwestern parts.

OLR tends to larger values when SLE is large, but is reduced by the cloud and water vapor effects, which of course are much stronger (Figs. 3\&4) in February 1990. The differences in OLR $\left(\mathrm{Wm}^{-2}\right)$ between those two monthly means (from the Pathfinder Path A) are presented as Fig.5.

From Table 1 we note that SLE in Feb. 1990 was larger than in Feb. 1996 by $15.8 \%$, but OLR was larger by only $3.7 \%$. This disproportionally small increase stems from the more robust greenhouse effects by the 1990 atmosphere. The ratio OLR/SLE was only 0.679 in 1990 , as compared to 0.758 in 1996 . This comparison establishes the 1990 vs 1996 difference in the greenhouse-effect as substantial. 
Our intention now is to evaluate the contribution of the reduced losses to space into an impact on $\mathrm{T}_{\mathrm{S}}$. For this, we require information about the partitioning of OLR between the emission effectively from the surface (which is dominant in the $11 \mu \mathrm{m}$ band) and that effectively from the atmosphere (which is dominant at wavelengths $15-20 \mu \mathrm{m}$ ). In this preliminary study, we resort to a simplified approach, assuming that an $1 \mathrm{~K}$ increase in $T_{s}$ produces OLR larger by $1 \mathrm{Wm}^{-2}$ ( $\mathrm{Wu}$ and Susskind, 1990). Thus, $\mathrm{T}_{\mathrm{s}}$ of $272.9 \mathrm{~K}$ (an increase by $9.8 \mathrm{~K}$ over the reported $1996 \mathrm{~T}_{\mathrm{s}}$ ) should produce OLR of 205.4 $\mathrm{Wm}^{-2}$ (adding $9.8 \mathrm{Wm}^{-2}$ to the observed OLR of $195.6 \mathrm{Wm}^{-2}$ ) above the 1990 atmosphere. This forecast value of OLR is higher by $2.6 \mathrm{Wm}^{-2}$ than what was actually reported above the 1990 atmosphere. Relating this enhancement of the greenhouse effect by the 1990 atmosphere (that is, this reduction in the heat loss to space) to the surface temperature effect, we evaluate the consequence for $T_{s}$ as $2.6 \mathrm{~K}$. Thus, the greenhouseeffect feedback constitutes some $26 \%$ of the combined (the direct inflow-effect, and the feedback) difference in $T_{\mathrm{s}}$ of $9.8 \mathrm{~K}$, and $36 \%$ of the direct (combined less the feedback) $7.2 \mathrm{~K}$ effect.

\section{Discussion and conclusions}

The aim of this preliminary study was to analyze the relationship in winter between the ocean-to-land advection and the greenhouse-factor parameters over the central European region, 50-60 ${ }^{\circ} \mathrm{N} ; 5-35^{\circ} \mathrm{E}$, which we regard as a "corridor" to the nearsurface flow. It was advantageous in the study to have four different datasets choosing the appropriate dataset for each parameter. Still, it is not a definitive analysis, considering that we only compare two monthly scenarios and do not perform detailed radiative transfer calculations.

The SSM/I dataset of ocean surface winds is a reliable information source, especially accurate in regions such as the eastern North Atlantic, where comparisons with 
the surface measurement are ample. Ocean-surface winds are highly variable on time scales of a pentad and shorter. The effects over land lag (depending on the wind speed and the distance from the ocean) the over-the-ocean wind observations. It was quite fortuitous, however, that our pentad-by-pentad analysis for the two selected Februaries showed $I_{\text {mat }}\left(\mathrm{m} \mathrm{s}^{-1}\right)$ fluctuating in a very narrow range $\left(10.6 \mathrm{~m} \mathrm{~s}^{-1}\right.$ in $1990,2.4 \mathrm{~m} \mathrm{~s}^{-1} 1996$; in Fig. 1), so we could analyze monthly averages in the other datasets (rather than forced to conduct pentad-by-pentad analysis).

Pathfinder Path A dataset is quite reliable for large region assessment, but incomplete coverage of small regions (gaps in satellite observations) introduce some inaccuracies into the averages. Data from two satellites were averaged for Feb. 1990, and another two for Feb. 1996, which might have introduced small discrepancies because of differences in the inter-satellite calibrations. A drawback of this dataset is that lower clouds tend to be underestimated in the presence of higher clouds, and for that reason we resorted to the NCEP/NCAR Reanalysis for middle and high clouds.

The mechanism underlying the enhancement of the greenhouse effect involves the vertical motions at $700 \mathrm{mb}$, above the low troposphere. We found the ECMWF dataset most useful for this evaluation. On Feb. 1,1990, 12 Z 12 hours after especially strong southwesterlies over the eastern North Atlantic (SSM/I data), we noted cells of strong updrafts forming a semicircle around western Europe, from Scandinavia to the Mediterranean (Otterman et. al., 2001)

The difference $G$ between the surface emission SLE and OLR specifies the greenhouse effect $\left(\mathrm{Wm}^{-2}\right)$ in a given surface/atmosphere scenario. $\mathrm{G}$ in 1990 was much greater than in 1996 because the effectiveness of the 1990 atmosphere in reducing heatloss to space was far greater in 1990, and because SLE was much larger then. To compare two different atmosphere/surface scenes, we must assess the greenhouse effect relative to SLE. We assume that a $1 \mathrm{~K}$ increase in $T_{s}$ produces an $1 \mathrm{~W} \mathrm{~m}^{-2}$ increase in OLR (Wu and Susskind, 1990). The feedback effect calculated on this basis is likely to 
be on the order of $2.6 \mathrm{~K}$, a substantial fraction of the total (direct and feedback) difference of $9.8 \mathrm{~K}$ in the surface temperature. Based on this value of the feedback, the direct effect is estimated as $7.2 \mathrm{~K}(9.8 \mathrm{~K}-2.6 \mathrm{~K})$, and its reinforcement by the feedback stands at $36 \%$. This analysis establishes the enhancement of the greenhouse effect, i.e., the increased downward longwave flux primarily associated with greater cloudiness, as a substantial positive feedback to the direct effect, which is the southwesterly inflow of warm air to the low troposphere over Europe.

Trends for warmer winters in Europe have been observed ( Ross et al., 1996; Demaree, 2001). Several studies reported the trend to stronger winds over the North Atlantic for the recent decades (Bacon and Carter, 1991; Kushnir et al., 1997; Gulev and Hasse, 1999). Is the trend in the temperature in Europe related to the increasing strength of the North Atlantic surface winds? The strengthening advection might have contributed to increased cloudiness over land, which was observed by Keevallik and Russak (2001), and by Sun et al. (2000), for instance. Further studies of these important ocean-to-land advection effects, including simulation with General Circulation Models, are warranted.

\section{Acknowledgements}

Processing of Pathfinder Path A data by L. Iredell, General Sciences Co., is very much appreciated.

$$
I_{\text {na }}\left(\mathrm{m} \mathrm{s}^{-1}\right) \quad T_{\mathrm{s}}(\mathrm{K}) \quad \text { SI.E }\left(\mathrm{W} \mathrm{m}^{-2}\right) \mathrm{W}\left(\mathrm{g} \mathrm{cm}^{-2}\right) \quad \text { OLR }\left(\mathrm{W} \mathrm{m}^{-2}\right) \quad \mathrm{G}\left(\mathrm{Wm}^{-21} \quad\right. \text { OLR/SLE }
$$

$\begin{array}{llllllll}\text { Feb90 } & 10.6 & 272.9 & 298.76 & 10.3 & 202.8 & 95.96 & 0.679 \\ \text { Feb96 } & 2.4 & 263.1 & 258.06 & 5.9 & 195.6 & 62.46 & 0.758\end{array}$

Table 1. Index $I_{n a}$ and the greenhouse-effect parameters: comparison of February 1990 with February 1996. 


\section{References}

Atlas, R. Hoffman, R.,N., Bloom, S. C., Jusem, J.C. and Ardizonne, J., A multiyear global surface wind velocity dataset using SSM/I wind observations. Bull. Am. Meteor. Soc. $\mathbf{7 7}, 869-882.1996$

Bacon, S., and D.J.T. Carter. Wave climate changes in the North Atlantic and North Sea, Int.J. Climatol., 11, 545-558, 1991.

Demarée, G., P.-J. Lachaert, T. Verhoeve and E. Theon. The long-term daily Central Belgium Temperature (CBT) time-series 1767-2000. History of the Instrumental Meteorological Observations in Belgium, invited paper, Special Issue, Climatic Change, 2001.

Gulev, D. K., and L. Hasse. Changes of wind waves in the North Atlantic over the last 30 years, Int. J. Climatol., 19, 1091-1117, 1999.

Hurrell, J.W.. Influence of variations in extratropical wintertime teleconnections in Northern Hemisphere temperature, Geophys. Res. Lett., 23, 665-668, 1996.

Kalnay, E., et al. The NCEP/NCAR 40-year reanalysis project, Bull. Amer. Meteorol. Soc., 77, 437-471, 1996.

Keevallik, S, and V. Russak, Changes in the amount of low clouds in Estonia (19551995), Int. J. Climatol., 21: 389-397,2001.

Kistler, R., E. Kalnay, W. Collins, S. Saha, G. White, J. Wollen, M. Chelliah, W. Ebisuzaki, M. Kanumitsu, V. Kousky, Huug van den Dool, R. Jenne, and M. Fiorino. The NCEP/NCAR 50-year Reanalysis: Monthly-means CD-ROM and Documentation, Bull. Amer. Meteor. Soc., 82, 247, 2001.

Kushnir, Y., V.J. Cardone, J.G. Greenwood, and M.A. Cane. The recent increase in North Atlantic wave heights, J. Climatol, 10, 2107-2113, 1997.

Otterman, J., R. Atlas, J. Ardizzone, D. Starr, J.C. Jusem, and J. Terry. Relationship of late-winter temperatures in Europe to North Atlantic surface winds: A correlation analysis, Theor. and Appl. Climatol., 64, 201-211, 1999.

Otterman, J., J. Ardizzone, R. Atlas, H. Hu, J.C. Jusem, D. Starr. Winter-to-spring transition in Europe $48-54^{\circ} \mathrm{N}$ : from temperature control by advection to control by insolation, Geophys. Res. Lett., 27, 561-564, 2000.

Rogers, J. North Atlantic storm track variability and its association to the North Atlantic oscillation and climate variability of Northern Europe, J. Climate, 10, 1635-1647, 1997. 
Otterman, J., et al. The variability of winter air temperature in mid-latitude Europe, Geographia Polonica 74, 67-77,2001.

Ross, R.J., J. Otterman, D. O. Starr, W. P. Elliott, J. K. Angell and J. Susskind. Regional trends of surface and tropospheric temperature and evening-morning temperature difference in northern latitudes, Geophys. Res. Lett., 23, 3179-3182, 1996.

Sun B., P. Ya. Groisman, R.S. Bradley, F. T. Keimig, Temporal changes in the observed relationship between cloud cover and surface air temperature, J. Climate, 13, 4341-4357. 2000.

Susskind J., Piraino P. ,Rokke L., Iredell L., Mehta A., , Characteristics of the TOVS Pathfinder Path A Dataset, Bulletin of the American Meteorol. Soc., 7, 1449-1472. 1997.

Wu, M.-L.C., and J. Susskind, Outgoing long-wave radiation computed from HIRS2/MSU soundings, J. Geophys. Res., 95, 7479-7602, 1990. 


\section{List of Figures}

1. Index $I_{\text {na }}$ plotted vs the pentad date for winter $1989 / 90$ (solid line) and 1995/96 (dotted line).

2. Skin surface temperature $T_{5}$ (normalized to $7^{\frac{30}{10}} \mathrm{am}$ ), in the area $46-60^{\circ} \mathrm{N} ; 5-35^{\circ} \mathrm{E}$; upper Figure for February, 1990 middle Figure for February 1996 the difference in the lower figure.

3. Total preciptable water $\left(\mathrm{g} \mathrm{cm}^{-2}\right)$; upper Figure for February 1990, middle Figure for February 1996, the difference in the lower Figure

4. High cloud-cover fraction (above $350 \mathrm{mb}$ ), upper Figure for February 1990, middle Figure for February 1996, the difference in the lower Figure.

5. OLR; upper Figure for February 1990, middle Figure for February 1996, the difference in the lower Figure. 


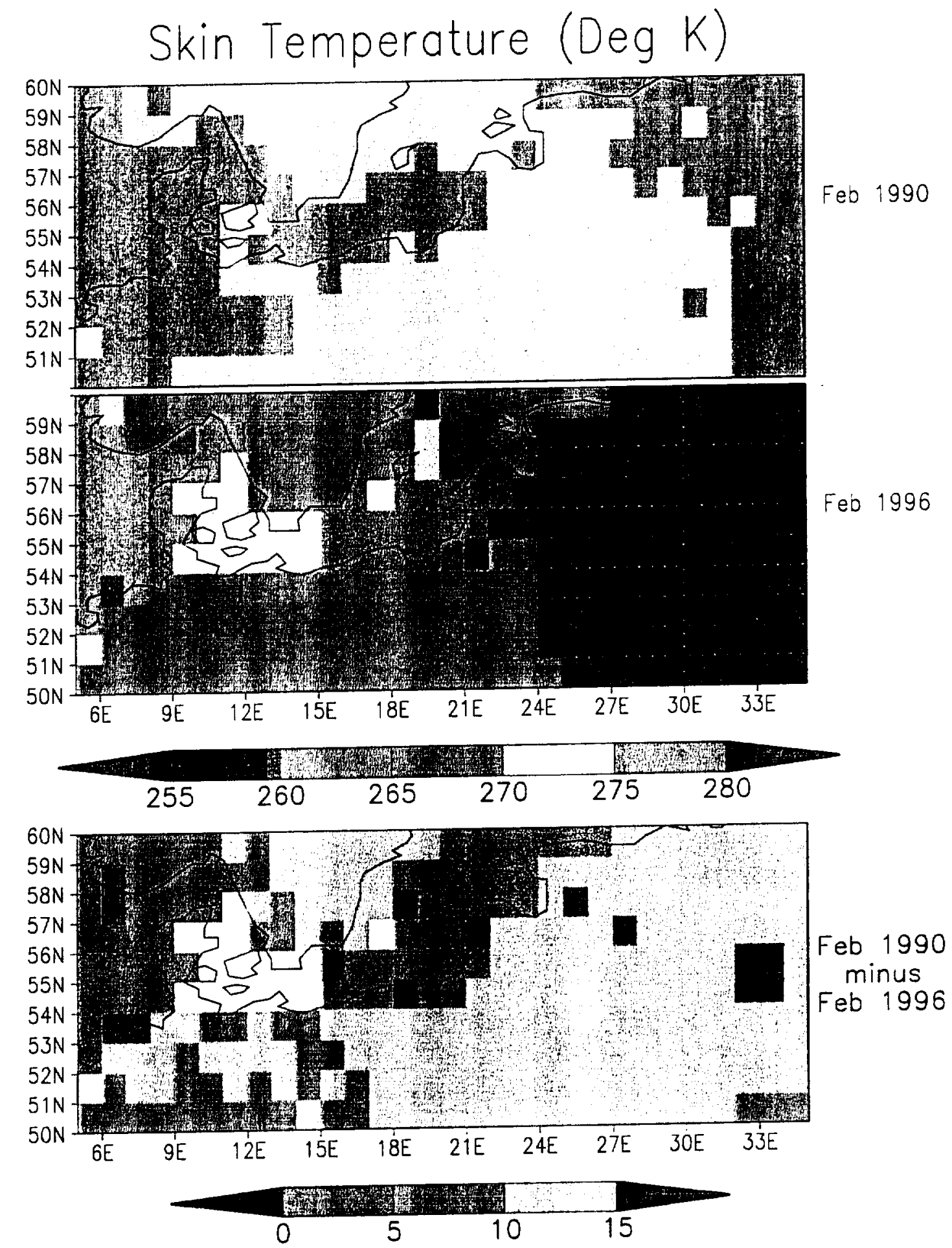

Fig. 2 


\section{Total Precipitable Water}
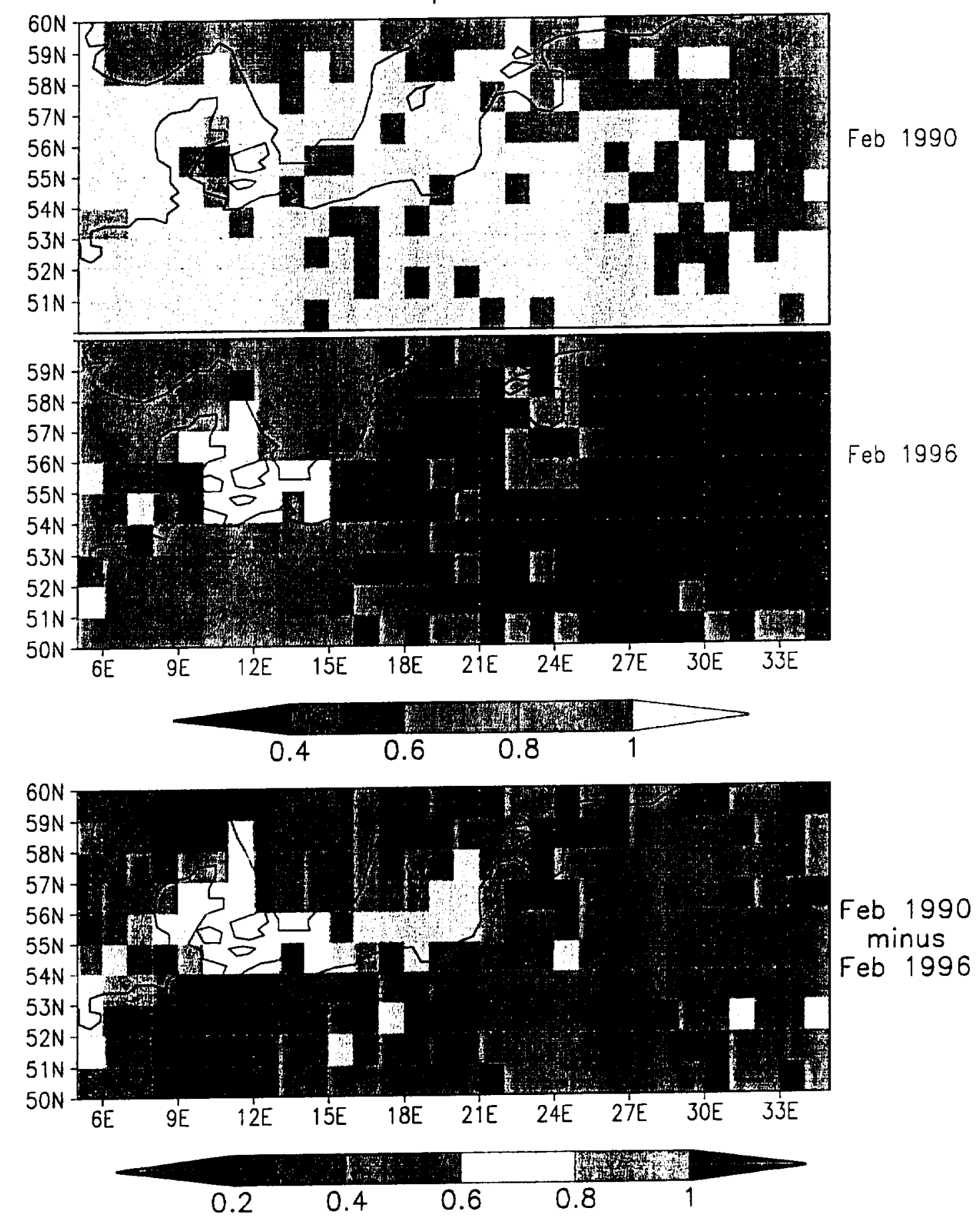

Fig. +3 


\section{High cloud cover (percent)}

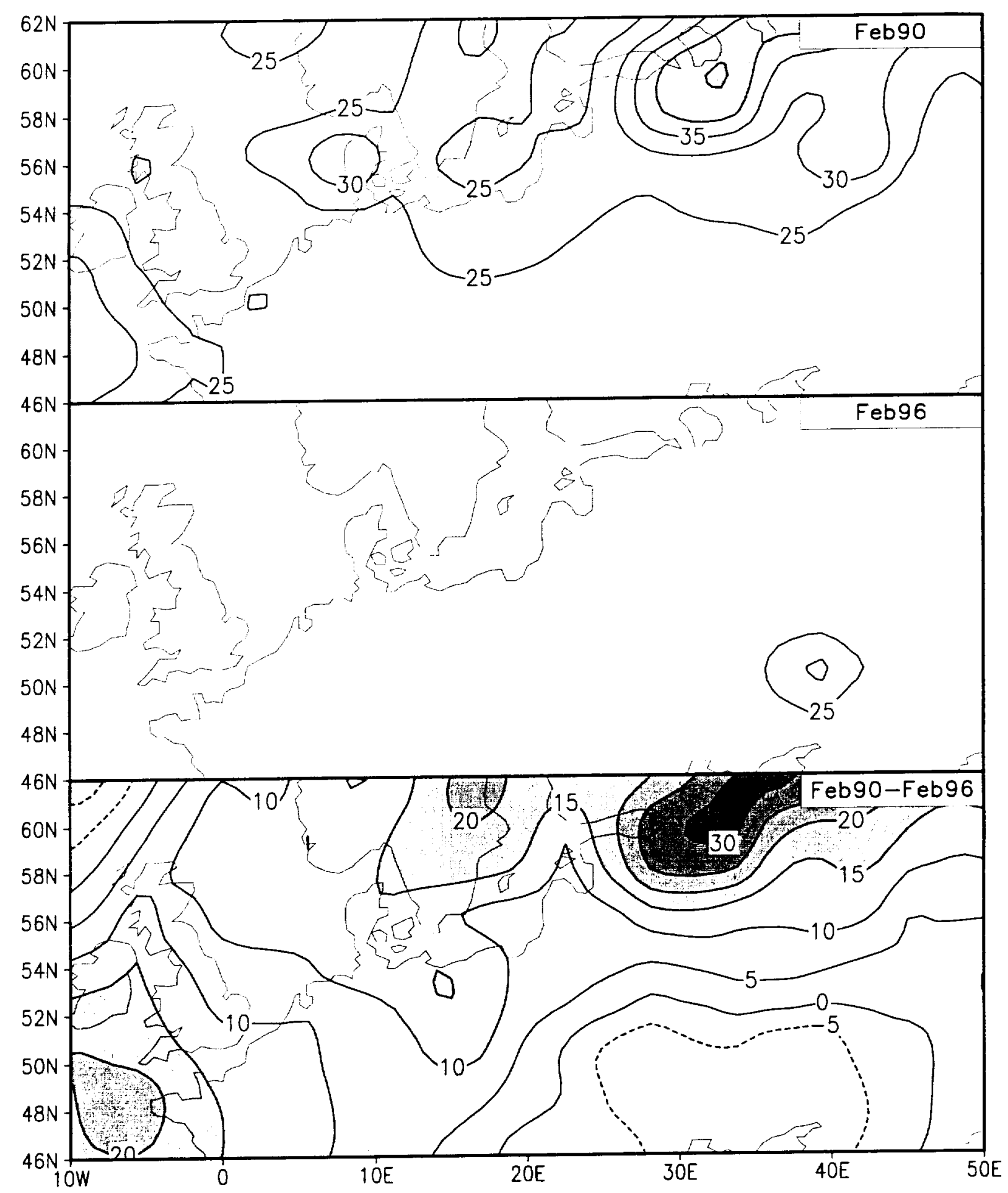

Fig. 4 


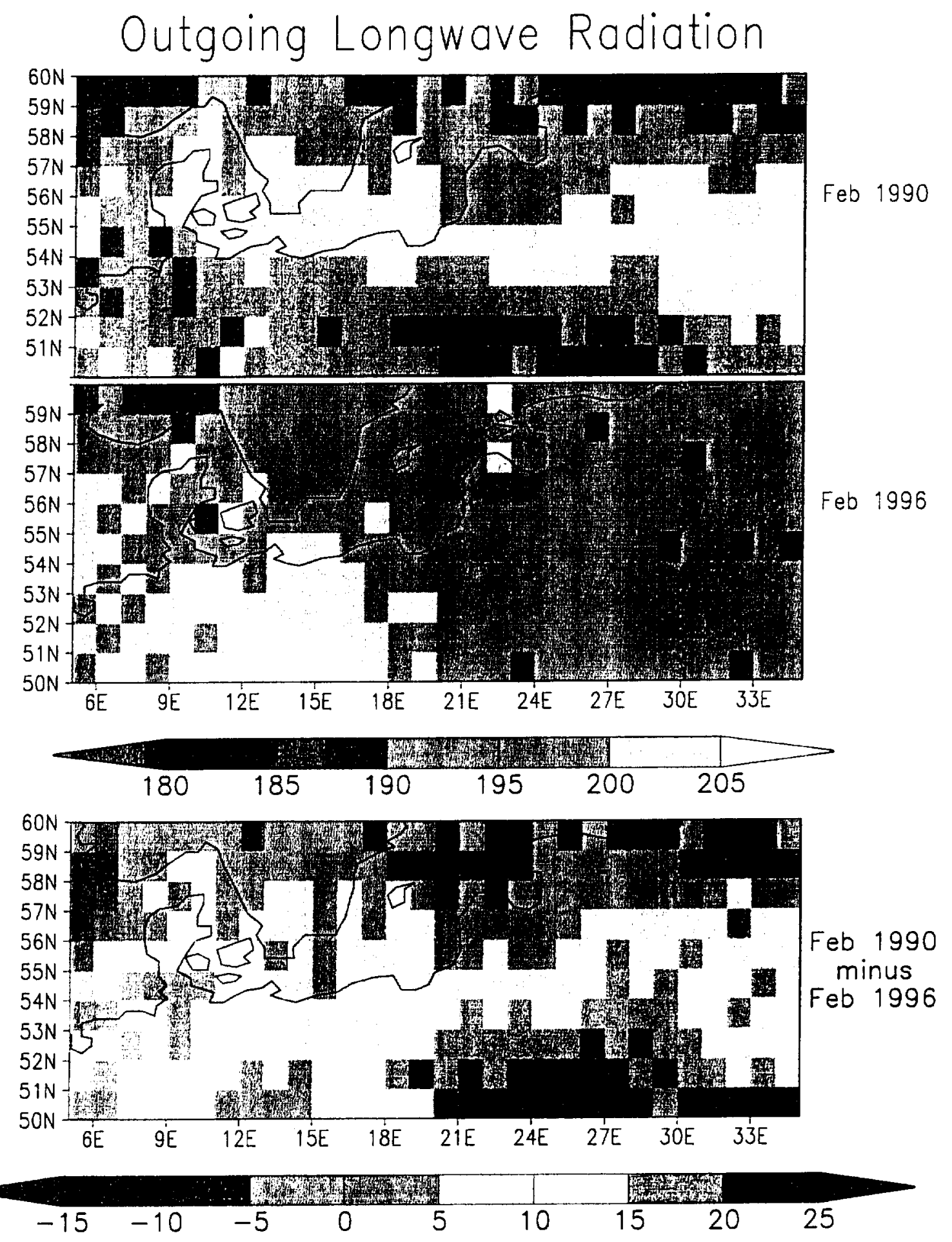

Fig. 5 